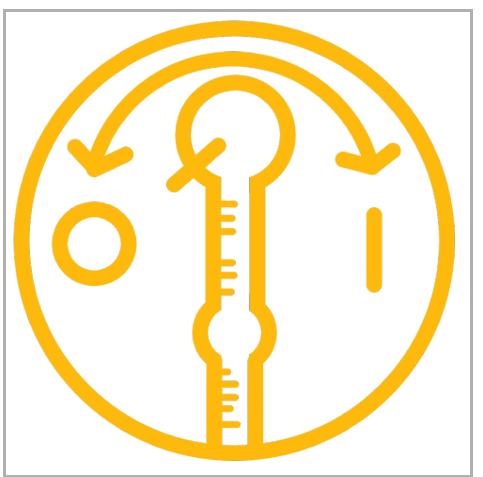

OCT 09, 2019

\section{open Әaccess}

DOI:

dx.doi.org/10.17504/protocol s.io. 72 bhqan

Protocol Citation: Junyan Qian 2019. Toehold switch assembly. protocols.io https://dx.doi.org/10.17504/p rotocols.io.72bhqan

License: This is an open access protocol distributed under the terms of the Creative Commons Attribution License, which permits unrestricted use, distribution, and reproduction in any medium, provided the original author and source are credited

Protocol status: Working We use this protocol and it's working

Created: Oct 08, 2019

Last Modified: Oct 09, 2019

PROTOCOL integer ID: 28451

Keywords: PCR, Q5, Toehold assembly, iGEM

\section{(3) Toehold switch assembly}

Junyan

Qian $^{1}$

${ }^{1}$ EPFL

iGEM EPFL

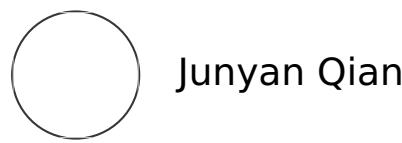

\section{ABSTRACT}

General toehold assemble method using NEB Q5 High-Fidelity 2x Master Mix. Here we took Boir Noir toeholds as an example, it has four candidates we wanted to test. In order to have a higher yield, run 5 reactions for each candidates.

\section{MATERIALS}

\section{MATERIALS}

\section{$8 \%$} Q5 High-Fidelity 2X Master Mix - 500 rxnsNew England Biolabs Catalog \#M0492L

8 UltraPure $^{\mathrm{TM}}$ DNase/RNase-Free Distilled Water Thermo Fisher Scientific Catalog \#10977015

88 Toehold primer IDT

\& Commin primer IDT

$\$ 8$ DNA template Contributed by users

\title{
PCR preparation
}


1 Prepare 4 effendorfs label them, each one will contain the master mix of a certain toehold primer. Attention: Keep the polymerase on ice avoiding denaturation.

(Order of pipetting: $\mathrm{H}_{2} \mathrm{O}->\mathrm{Q} 5$ MasterMix -> primers)

\begin{tabular}{|c|c|c|c|c|c|}
\hline $\begin{array}{l}\text { Numb } \\
\text { er of } \\
\text { reacti } \\
\text { ons } \\
\text { per } \\
\text { Maste } \\
\text { r mix: }\end{array}$ & 5 & & & & \\
\hline \multirow{2}{*}{$\begin{array}{l}\text { Reacti } \\
\text { on } \\
\text { Volu } \\
\text { me: }\end{array}$} & 25 & & & & \\
\hline & $\begin{array}{l}\text { Refer } \\
\text { ence } \\
(25 \\
\text { uL) }\end{array}$ & $\begin{array}{l}\text { Maste } \\
\text { r mix1 }\end{array}$ & $\begin{array}{l}\text { Maste } \\
\text { r mix2 }\end{array}$ & $\begin{array}{l}\text { Maste } \\
\text { r mix3 }\end{array}$ & $\begin{array}{l}\text { Maste } \\
\mathrm{r} \text { mix4 }\end{array}$ \\
\hline $\begin{array}{l}\text { DNA } \\
\text { templ } \\
\text { ate( }(\sim \\
60 n g / \\
\text { uL) }\end{array}$ & 1 & & & & \\
\hline $\begin{array}{l}\text { Com } \\
\text { mon } \\
\text { prime } \\
\text { r } \\
(10 \mu \\
\text { M) }\end{array}$ & 1.25 & 6.25 & 6.25 & 6.25 & 6.25 \\
\hline $\begin{array}{l}\text { Toeh } \\
\text { old_pr } \\
\text { imer- } \\
1(10 \bar{\mu} \\
\text { M) }\end{array}$ & 1.25 & 6.25 & & & \\
\hline $\begin{array}{l}\text { Toeh } \\
\text { old_pr } \\
\text { imer_- } \\
2(10 \bar{\mu} \\
\text { M) }\end{array}$ & & & 6.25 & & \\
\hline $\begin{array}{l}\text { Toeh } \\
\text { old_pr } \\
\text { imer_- } \\
3(10 \bar{\mu} \\
\mathrm{M})\end{array}$ & & & & 6.25 & \\
\hline $\begin{array}{l}\text { Toeh } \\
\text { old_pr } \\
\text { imer_ } \\
4(10 \bar{\mu} \\
\text { M) }\end{array}$ & & & & & 6.25 \\
\hline $\begin{array}{l}\text { Q5 } \\
\text { Maste } \\
\text { rMix }\end{array}$ & 12.5 & 62.5 & 62.5 & 62.5 & 62.5 \\
\hline
\end{tabular}




\begin{tabular}{|l|l|l|l|l|l|}
\hline $\begin{array}{l}\text { H2O } \\
\text { (DNA } \\
\text { se } \\
\text { RNAs } \\
\text { e free } \\
\text { distill) }\end{array}$ & 9 & 45 & 45 & 45 & 45 \\
\hline Total & 25 & 120 & 120 & 120 & 120 \\
\hline
\end{tabular}

2 Pipette up and down mix the master mix thoroughly.

3 Take 20 PCR tubes label them, pipette $24 \mu$ of the master mix into the tubes accordingly.

$4 \quad$ Add $1 \mu$ of DNA template into each PCR tubes

\section{PCR}

5

PCR machine setting: Calculate the reaction temperature according to the primer sequence using NEB online Tm calculator: http://tmcalculator.neb.com/\#!/main

\begin{tabular}{|l|l|l|l|l|l|l|}
\hline $\begin{array}{l}\text { Templat } \\
\text { e }\end{array}$ & $\begin{array}{l}\text { Fw } \\
\text { Prime } \\
r\end{array}$ & $\begin{array}{l}\text { Rev } \\
\text { Prime } \\
\mathrm{r}\end{array}$ & $\begin{array}{l}\text { Lengt } \\
\mathrm{h}\end{array}$ & $\begin{array}{l}\text { Elong } \\
\text { ation } \\
\text { time }\end{array}$ & $\begin{array}{l}\text { Tm - } \\
\text { Q5 }\end{array}$ & $\begin{array}{l}\text { Tm } \\
\text { used }\end{array}$ \\
\hline $\begin{array}{l}\text { DNA } \\
\text { template }\end{array}$ & $\begin{array}{l}\text { Toeh } \\
\text { old } \\
\text { prime } \\
\mathrm{r}\end{array}$ & $\begin{array}{l}\text { Com } \\
\text { mon } \\
\text { prime } \\
\mathrm{r}\end{array}$ & $\begin{array}{l}900- \\
1000\end{array}$ & 30s & T1/T2 & $\begin{array}{l}\text { Avera } \\
\text { Ae } \\
(\mathrm{T} 1, \mathrm{~T} \\
2)\end{array}$ \\
\hline
\end{tabular}

6 Thermo cycle setting: 


\begin{tabular}{|c|c|c|}
\hline $\begin{array}{l}\text { Initial } \\
\text { Denat } \\
\text { uratio } \\
n\end{array}$ & $98^{\circ} \mathrm{C}$ & $\begin{array}{l}30 \\
\text { secon } \\
\text { ds }\end{array}$ \\
\hline \multirow{3}{*}{$\begin{array}{l}25- \\
35 \\
\text { Cycle } \\
\text { s }\end{array}$} & $98^{\circ} \mathrm{C}$ & $\begin{array}{l}5-10 \\
\text { secon } \\
\text { ds }\end{array}$ \\
\hline & $\mathrm{T}^{\circ} \mathrm{C}$ & \begin{tabular}{|l}
$10-$ \\
30 \\
secon \\
ds
\end{tabular} \\
\hline & $72^{\circ} \mathrm{C}$ & $\begin{array}{l}20- \\
30 \\
\text { secon } \\
\text { ds/kb }\end{array}$ \\
\hline $\begin{array}{l}\text { Final } \\
\text { Exten } \\
\text { sion }\end{array}$ & $72^{\circ} \mathrm{C}$ & $\begin{array}{l}2 \\
\text { minut } \\
\text { es }\end{array}$ \\
\hline Hold & $4^{\circ} \mathrm{C}$ & \\
\hline
\end{tabular}

Check detail :https://international.neb.com/protocols/2012/12/07/protocol-for-q5-high-fidelity2x-master-mix-m0492

$7 \quad$ Start the PCR reaction. 